\title{
コンクリート中への尿酸添加による鋼管材料の コンクリート/土潩系マクロセル腐食抑制手法の検討
}

中 山紀夫*，朝倉 祝 治**

* 独立行政法人 産業技術総合研究所 環境管理技術研究部門

** 横浜国立大学

\section{A Study of Potential Methods for Controlling Macro-cell Corrosion of Buried Steel Pipes in Concrete/Soil Systems by the Addition of Uric Acid as a Concrete Admixtures.}

\author{
Norio Nakayama* and Shukuji Asakura** \\ * Institute for Environmental Management Technology, \\ National Institute of Advanced Industrial Science and Technology (AIST), \\ ** Yokohama National University
}

\begin{abstract}
Severe localized corrosion of steel pipes, buried in concrete/soil systems (known as macro-cell corrosion), is induced by cathodic reactions on those steel surfaces that are located in the concrete, accompanied by anodic reactions (i.e., corrosion) on those surfaces that are located in the soil. The addition of cathodic inhibitors to the concrete, in the form of cement admixtures, is therefore expected to be an effective means of suppressing this phenomenon. Concrete test specimens (ordinary Portland cement; water/cement ratio: 61\%), containing uric acid as the inhibitor have been formulated and the inhibitory effect of uric acid on the macro-cell corrosion has been examined by the measurement, over 862 days, of the currents flowing between the steel (SGP) pipes embedded in the concrete test specimens and those buried in soil. Dry mixing of $10 \%$ uric acid by weight was shown to decrease the currents, which indicates that macro-cell corrosion can be effectively controlled by uric acid. Addition of 0.3 or $3 \%$ uric acid was ineffective. This tendency was also supported by the results of weight-loss measurements of steel pipes buried in soil. The inhibitory effect becomes more predominant as the measurement time increases (inhibition efficiencies: $64 \%$ for $0-862$ days, $78-91 \%$ for $297-862$ days).
\end{abstract}

Key words : concrete, macro-cell corrosion, soil, steel, pipe, inhibitor, uric acid

1. 緒

\section{言}

土壌中に埋設されているガス管等の鋼管の腐食は周囲 の土潩が均質な状態では緩やかに進行するが，コンクリ 一ト建築物内を貫通し土壤中に入る配管などでは数年で 局部的に腐食孔があくこともあり，この現象はコンクリ 一ト/土壤系マクロセル腐食（以下，マクロセル腐食と 略記する）と呼ばれている1).これは, 埋設鋼管がコン クリートを貫通したりコンクリート表面と接触したりす る場合に，鋼管周囲環境の $\mathrm{pH}$ が土壤中よりコンクリー トの方が高い（pH 12.5）ため，コンクリート中の鉄鋼電 位が土壤中の鉄鋼電位よりも貴となって両者の間に電池 が形成され，コンクリート側でカソード反応, 土壌側で アノード反応（腐食反応）が進行して両者の間に電流 (以下，マクロセル腐食電流と呼ぶ）が流れ，アノード 側の土壤中埋設鋼管の腐食が促進される現象である ${ }^{1,2}, 2$.

この対策の一つとして，コンクリート中にセメント添 加剂としてカソード反応抑制剤を添加することにより， 前記カソード反応を抑制しマクロセル腐食防止を図るこ とが考えられる，著者らはこの着想に基づき，添加剤と

テ305-8569 つくば市小野川 16-1（16-1, Onogawa, Tsukuba, 3058569 Japan)

** ７240-8501 横浜市保土ヶ谷区常盤台 79 番 5 号（79-5, Tokiwadai, Hodogaya-ku, Yokohama, 240-8501 Japan)
して尿酸を混合したセメントを用いてコンクリート試験 片を打設し，この試験片内部に埋め込んだ鋼管試験片と， 同じように土壌内部に埋設した鋼管試験片の間を流れる マクロセル腐食電流を実測し，短期間（116 日間）にお ける測定ではマクロセル腐食電流を抑制する効果がある ことを実証した ${ }^{3)}$.そこでこの結果を踏まえ，さらに継 続して長期間（746日間，前回との合計で 862 日間）に わたるマクロセル腐食電流測定を行うと共に, 測定終了 後, コンクリート及び土㙵内部の鋼管試験片の重量減少 測定を行い，尿酸によるマクロセル腐食抑制効果をさら に詳細に検討した。本報ではこの結果について報告す る.

\section{2. 実験}

\section{1 コンクリート試験体}

本実験は前報告の測定（116 日間）に引き続き，同じ 試験体を用いて電流測定を継続して行ったもので，使用 したコンクリート試験体及び電流測定装置は前報のもの と同一である ${ }^{3)}$ 。この実験に使用した，内部に SGP 鋼管 試験片を配置したコンクリート試験体 $(88 \times 129 \times 61$ mm）の形状を Fig. 1 に，この試験体におけるセメント， 粗骨材, 細骨材の配合比を Table 1 に示す.コンクリー トの水/セメント比は約 $61 \%$ である.内部の SGP 鋼管試 験片の形状を Fig. 2 に示す。これは通常黒管と呼ばれる

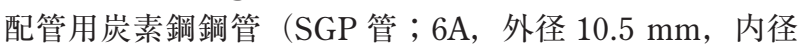


$6.5 \mathrm{~mm} ）$ の黒色の表面皮膜を研磨により除去して鉄鋼材 料表面を露出させ, さらに\#1000 のエメリー紙で研磨し たものである。これを，アセトンで超音波脱脂した後， 両端をゴム栓で塞ぎ, さらに $95 \mathrm{~mm}$ を露出（露出面 積 : 約 $\left.31.3 \mathrm{~cm}^{2}\right)$ させて両端を塩化ビニール製絶縁テー プで絶縁したものを実験に供した。土㙵中に埋設するも

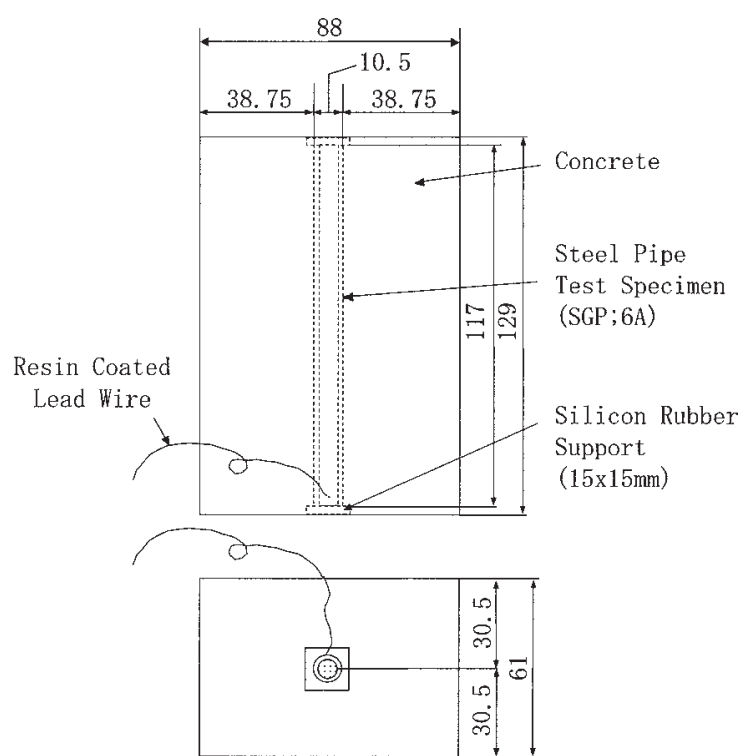

Fig. 1 Schematic illustration of concrete test specimen.

Table 1 Concrete mixture design.

\begin{tabular}{lccll}
\hline & Water & Cement & $\begin{array}{l}\text { Fine } \\
\text { Aggregate }\end{array}$ & $\begin{array}{l}\text { Coarse } \\
\text { Aggregate }\end{array}$ \\
\hline $\begin{array}{l}\text { Weight } \\
(\mathrm{kg})\end{array}$ & 0.263 & 0.428 & 1.387 & 1.780 \\
\hline $\begin{array}{l}\text { Weight } \\
\text { Ratio }(\%)\end{array}$ & 6.83 & 11.1 & 35.9 & 46.1 \\
\hline
\end{tabular}

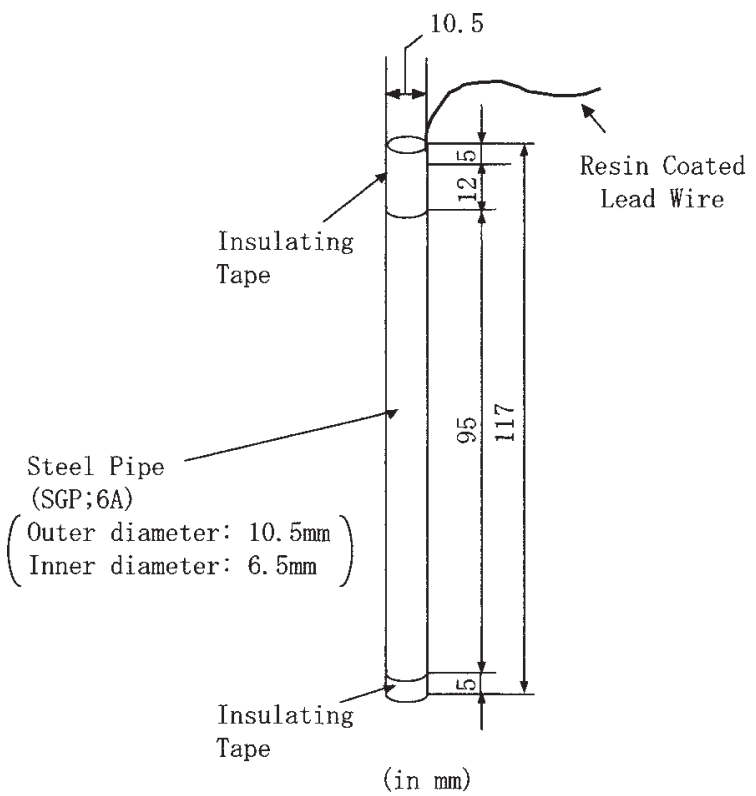

Fig. 2 Schematic illustration of SGP steel pipe test specimen.
のも同一の形状のものを使用した.

コンクリート試験体は尿酸をセメント重量比 $0.3 ， 3.0$, 10\%添加したもの，及び比較用としてこれを添加しない ものを，それぞれ 2 個ずつ作成した。尿酸はセメント (普通ポルトランドセメント), 細骨材 (鬼怒川河川敷砂), 粗骨材 (3 分砂利 : 粒径が約 $20 \mathrm{~mm}$ 以下のもの) 中に粉 末で混合し，これに純水を加えて生コンクリートを混練 した。これを用いて Fig. 2 の形状に打設し, 約 2 週間室 温（約 $23 \sim 26^{\circ} \mathrm{C}$ ) で封緘養生したものを, 試験体として 使用に供した。

\section{2 測 定 方法}

Fig. 3 に示すように，樹脂製試験槽（580×490×180 $\mathrm{mm}$ ）内部に土壤（砂質細粒土）を $70 \mathrm{~mm}$ の深さで充填 し，この中に Fig. 2 の形状の SGP 鋼管試験片を埋設（土 袞表面より深さ $60 \mathrm{~mm}$ ） した後, この真上に前節で作成 した各濃度の尿酸を含むコンクリート試験体をそれぞれ 設置した ${ }^{3)}$ 。これらのコンクリート試験体それぞれにつ いて，試験体内部に埋めこまれた SGP 鋼管試験片と土䁃 中の SGP 鋼管試験片とを Fig. 4 に示すように時間制御機 能を持つリレーを備えた計測システムに結線し, 両者の 間を流れるマクロセル腐食電流を測定した。このリレー は，8 個の SGP 鋼管試験片を順次，1 日に 1 度，同時刻 に, 45 分ずつ無抵抗電流計に接続してマクロセル腐食電 流を測定するものであり，この测定結果は記録用コンピ

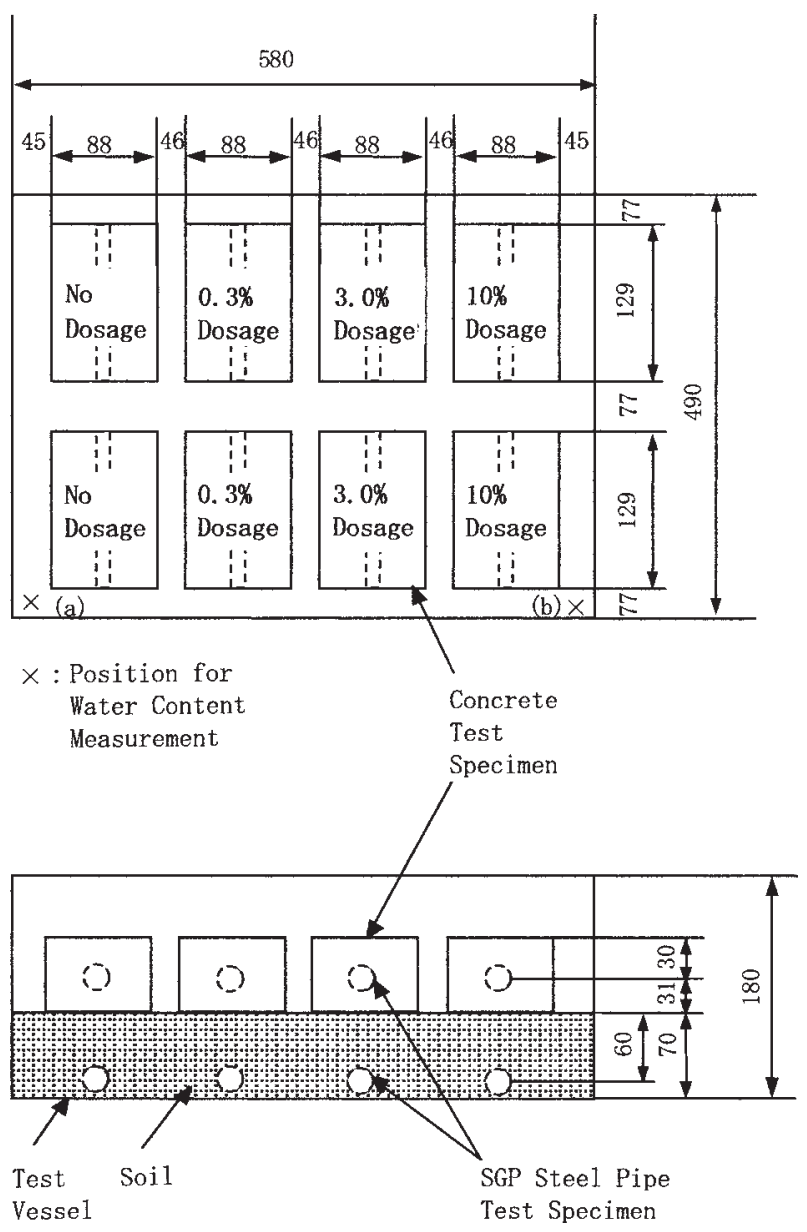

Fig. 3 Schematic illustration of test container. 


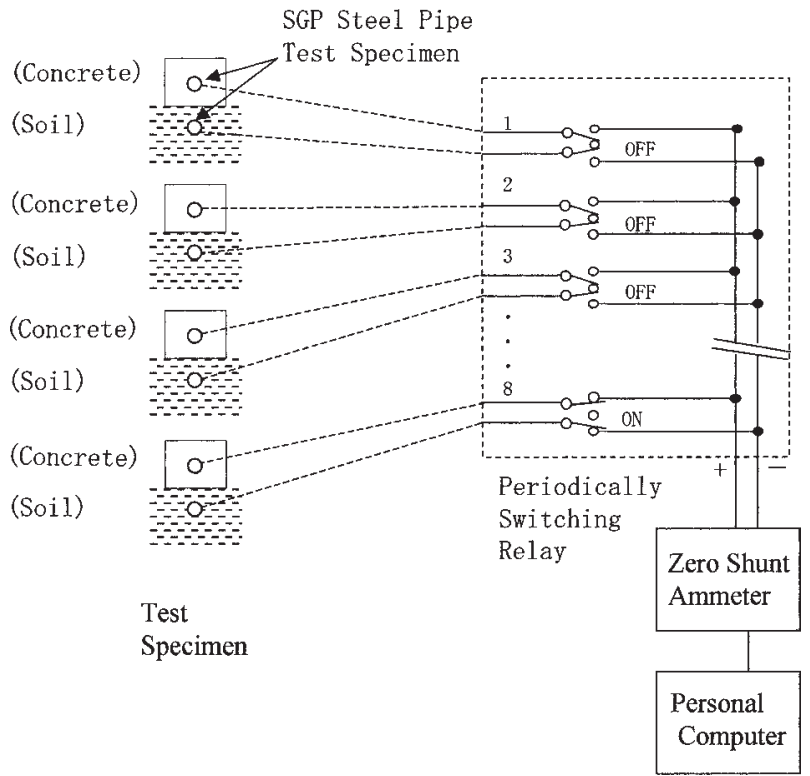

Fig.4 Schematic illustration of method used for measurement of macro-cell corrosion current.

ユータに記録される．測定を行っていない間，それぞれ のコンクリート試験体内部の SGP 鋼管試験片とこれと対 をなす土壤中の鋼管試験片は導通されたままであり，測 定を行う際にはそのまま無抵抗電流計に接続される仕組 みとなっている。このため両試験片の間の導通は常に保 たれ，電流が遮断されることによりマクロセル腐食反応 が阻害されることはない。実験はすべて室温で実施し， 試験槽の温度制御は行わなかった。実験期間中，K熱電 対を用いて室温の変化を測定し，マクロセル腐食電流值 と共に記録した。電流值の測定は通算で 862 日間経過す るまで実施した．測定終了後コンクリート中の SGP 鋼管 試験片の目視観察や土壤中の試験片の重量減少測定を行 い，マクロセル腐食抑制効果を詳細に検討した。重量減 少の測定は, 試験片表面のさびを可能な限り機械的に除 去し, 残った酸化被膜を $0.07 \mathrm{~mol} / \mathrm{dm}^{3}$ のヘキサメチレン テトラミンを含む $3 \mathrm{~N}$ の $\mathrm{HCl}$ 水溶液に $50^{\circ} \mathrm{C}$ で 3.5 分間浸 漬して溶出させた後 ${ }^{4}$, 実施した。土㙵の乾燥を防ぐた めに, 乾燥状態にあわせて, 適宜, 純水を樹脂製試験槽 内部に散水 $(122,196,220,224,239$ 日目に 1200，1500， $7000,2500,2500 \mathrm{~cm}^{3}$ ) した。さらに，239 日以降は自動 注水装置を用いて 1 2 日扮きに約 $250 \mathrm{ml}$ の純水を樹脂 製試験槽内部の土䁃中に注入した。マクロセル腐食電流 の測定には北斗電工製 HM-104 型無抵抗電流計を用い た。また土壤体積含水率の測定には DAIKI 製の DIK$311 \mathrm{~A}$ 型土䁃水分計を用いた。

\section{3. 結果および考察}

\section{1 マクロセル腐食電流測定結果}

0.3\%, 3.0\%, 10\%の尿酸を添加したコンクリート試験 体について全期間（0８62 日，前報の測定期間 116 日分 含む）に扔けるマクロセル腐食電流の測定結果（露出部 単位面積あたりに換算した電流密度)を Fig. 5〜7に示す。 同図においては比較のために尿酸を添加しないコンクリ

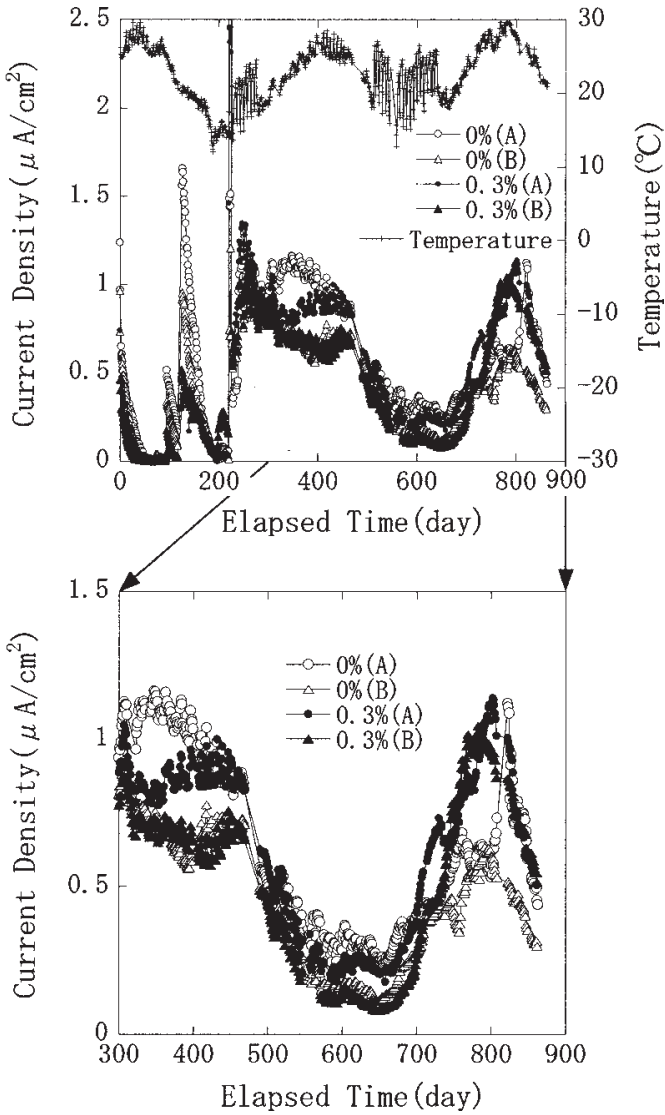

Fig. 5 Electric currents flowing between SGP steel pipe test specimens. (0-862 days; 0 and $0.3 \%$ uric acid dosage)

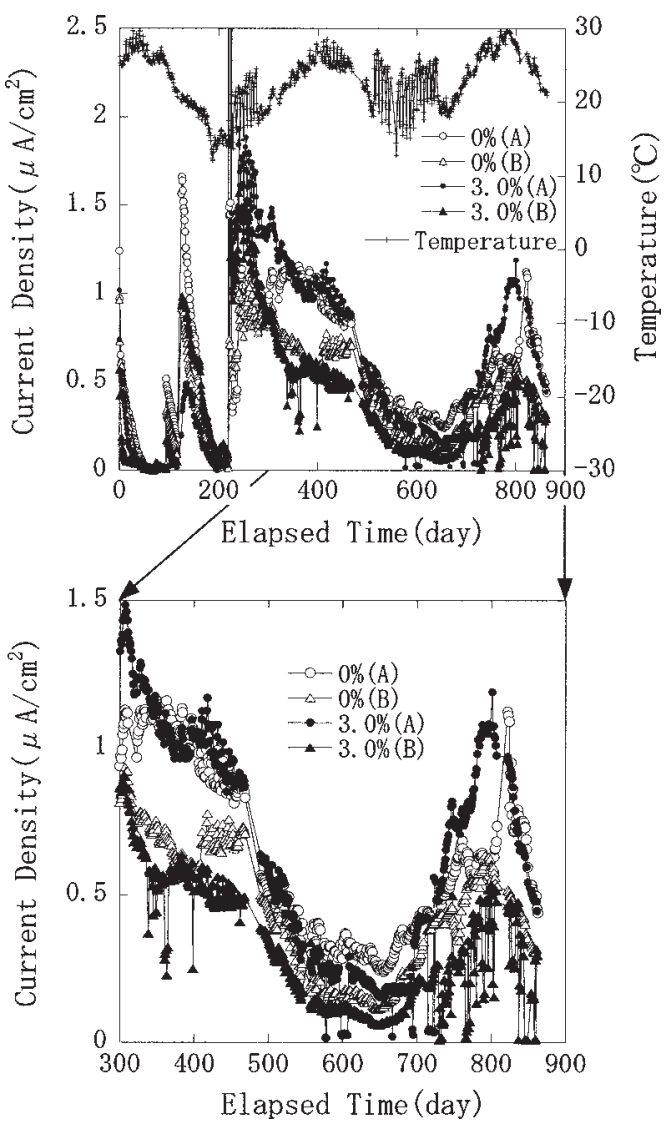

Fig. 6 Electric currents flowing between SGP steel pipe test specimens. (0-862 days; 0 and $3.0 \%$ uric acid dosage) 

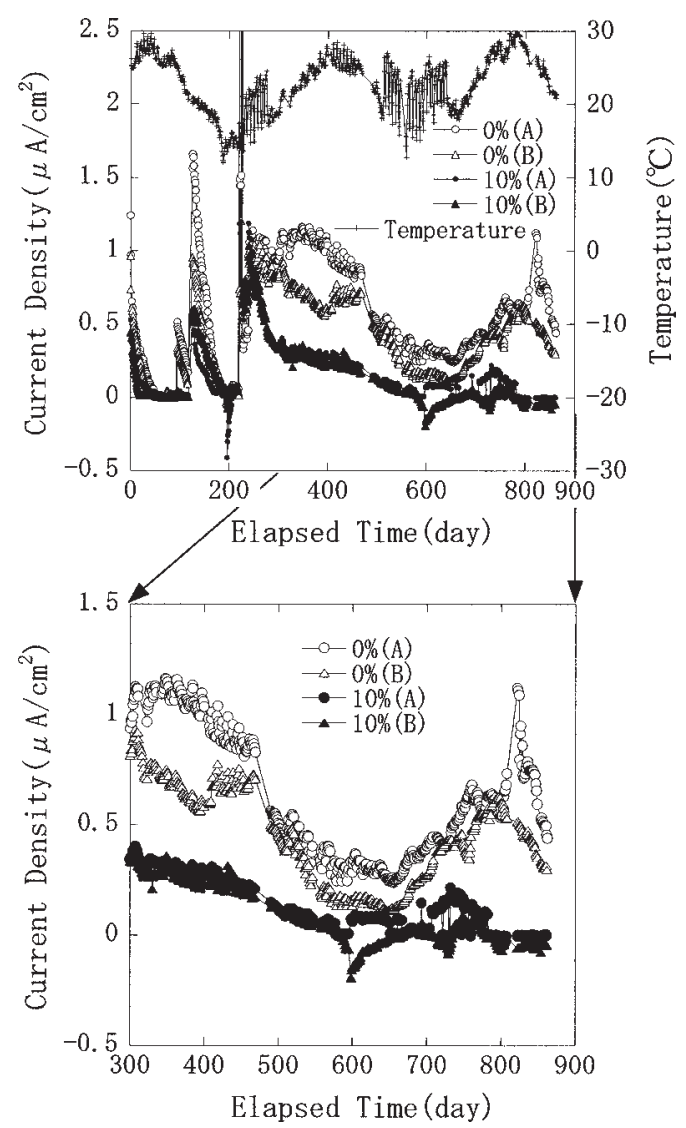

Fig. 7 Electric currents flowing between SGP steel pipe test specimens. (0-862 days; 0 and 10\% uric acid dosage)

ート試験体の測定結果も併せて示し，また，コンクリー 卜試験体から土㙵方向への電流を正の值として表示して いる. 連続注水開始前（0２39 日）においては試験槽に 散水した直後, 一時的に急激な電流の増大が見られたが, 連続注水開始後（239 日以降）は土懔中の含水率が安定 するとともに比較的安定した電流が得られた。この電流 がほぼ安定した期間（297～862 日）におけるマクロセル 腐食電流密度の測定結果を Fig. 5〜 7 の下部に, さらに詳 細に示した。連続注水以前の測定值と比較してすべての 試験体で電流值が増大する傾向があるのは, 土壤への注 水頻度を増大させたことに伴い, 土壤の含水率が増大し たことに起因すると考えられる。測定期間中の土壤の体 積含水率の変化を Table 2 に示す。表中, 測定位置 (a), (b) はFig. 3 に示す位置に対応している. 連続注水前 (122 日）に比較し，連続注水後（329～862 日）におい ては $14 \%$ 程度体積含水率が増大しており，これに伴い土 壌の比抵抗が減少し, 電流值が増大したものと考えられ る。測定位置 (a) と (b)における体積含水率の差は小さく 土壤含水率は試験槽内部でほぼ均一と予想されるので, 各試験体の電流值を相対的に比較するうえで, 特に問題 はないと考えられる.いずれの試験体についても約 500 〜640 日の期間に電流の減少が見られるが，これはこの 期間が冬季に当たり，室温が低下したためと考えられる. 今回の測定では尿酸を $10 \%$ 添加したコンクリート試験体 については二体とも安定したマクロセル腐食電流抑制効 果が見られた反面, 添加量が $3.0 \%$ 以下の場合は, 明暸 な電流抑制効果が見られなかった。
Table 2 Changes in volumetric moisture of soil in test containers.

\begin{tabular}{ccc}
\hline \multirow{2}{*}{$\begin{array}{l}\text { Elapsed } \\
\text { Time (days) }\end{array}$} & \multicolumn{2}{c}{ Measurement Position $^{* 1}$} \\
\cline { 2 - 3 } & (a) & (b) \\
\hline 122 & 0.323 & 0.307 \\
\hline 329 & 0.430 & 0.418 \\
\hline 356 & 0.446 & 0.409 \\
\hline 799 & 0.426 & 0.429 \\
\hline 862 & 0.446 & 0.439 \\
\hline
\end{tabular}

*1: positions illustrated in Fig. 3

腐食抑制効果を定量化しさらに詳細に特性を検討する ため, 前報告と同様に電流に基づくマクロセル腐食抑制 率（マクロセル腐食電流抑制率） $I_{\mathrm{c}}(\%)$ を式 (1)により 定義する ${ }^{3)}$.

$$
I_{\mathrm{c}}=100\left(i_{\mathrm{m}}{ }^{0}-i_{\mathrm{m}}\right) / i_{\mathrm{m}}{ }^{0}
$$

ここに, $i_{\mathrm{m}}{ }^{0}$ 及び $i_{\mathrm{m}}$ は尿酸添加前及び添加時におけるマ クロセル腐食電流の実測值（鉄鋼露出部表面積より換算 した電流密度 $; \mathrm{A} / \mathrm{cm}^{2}$ ) である. Fig. 7 の電流密度実測 值（尿酸 $10 \%$ 添加）を用いて求めた $I_{\mathrm{c}}$ の值（経時変化） を Fig. 8 に示す.ここで $i_{\mathrm{m}}{ }^{0}$ には当該時刻における尿酸 無添加の試験体 $(\mathrm{A}),(\mathrm{B})$ の電流密度測定值を平均した值 を用いている１0\%の添加によって，2 個の試験体とも 全期間を通じ，良好な電流抑制効果が得られた。 $I_{\mathrm{c}}$ は時 間の経過とともに上昇しており，抑制効果は長期にわた り持続するものと予想される。同図で試験体 (B)におい ては， $I_{\mathrm{c}}$ が一時的に 100\%を超える期間（593〜 675, 722 〜 742，798～862 日経過時）があるが，これは Fig. 7 にお いて，同時期に一時的に負方向（土壤よりコンクリート 試験体方向）の電流が観測されることに対応している. これは，この期間においては，通常とは逆に，コンクリ ート側の SGP 鋼管試験片がアノードとなり，コンクリー 卜内部の試験片のマクロセル腐食が進行していることを 示しているが，後述するようにこの腐食量は軽微であり， また負方向の電流は時間とともに減少する傾向を見せて いるので，実用上大きな問題は生じないものと予想され る.

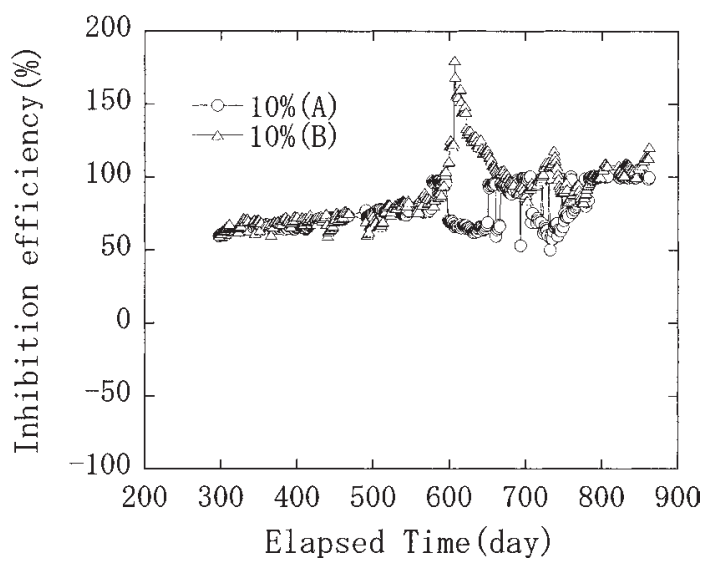

Fig. 8 Inhibition efficiency evaluated from the macro-cell corrosion current $\left(I_{\mathrm{c}}\right)$ as a function of time $(10 \%$ uric acid dosage). 


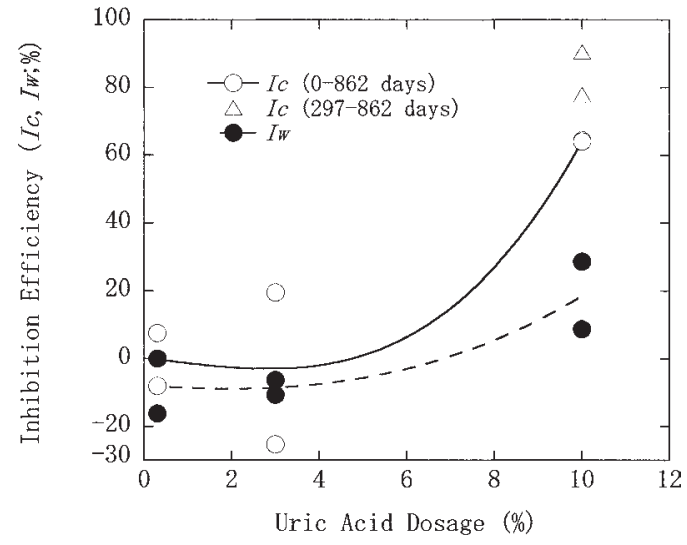

Fig. 9 Relationship between inhibition efficiency and uric acid dosage to the concrete test specimens. ( $I_{\mathrm{c}}$ : Efficiency evaluated from macro-cell corrosion current; $I_{\mathrm{w}}$ : efficiency evaluated from weight loss.)

各尿酸添加量の試験体について，Fig. 5〜 7 の全期間 （862 日間）における電流密度の平均值から式(1)により 求めた $I_{\mathrm{c}}$ の值 $\left(I_{\mathrm{c}}\right.$ の尿酸添加濃度依存性）を Fig. 9 に示 す.ここで， $i_{\mathrm{m}}{ }^{0}$ には尿酸を添加しない試験体について求 めた全期間における電流密度の平均值（試験体 $(\mathrm{A}) ： 0.57$ $\mu \mathrm{A} / \mathrm{cm}^{2}$, 試験体 (B) : $0.43 \mu \mathrm{A} / \mathrm{cm}^{2}$ ) を, さらに平均し た值 $\left(0.50 \mu \mathrm{A} / \mathrm{cm}^{2}\right)$ を用いている。また，負方向の電流 值は土壤中の SGP 鋼管試験片のマクロセル腐食を促進し ないため，これを 0 と補正して平均電流值を求めている. 3\%以下の添加では抑制効果が不安定であるが，10\%の 添加では安定した抑制効果（試験体 (A)，(B) とも約 64\%) が得られた。同図には，10\%添加の試験体について 297 〜862 日間のみの電流值を用いて同様に求めた $I_{\mathrm{c}}$ の值も 併せて示した。 $I_{\mathrm{c}}$ の值は全期間よりも増大（試験体 (A)：78\%，試験体(B)：91\%）しており，経時的に抑制 効果が増大することと対応している.これらのマクロセ ル腐食電流測定結果から，尿酸を $10 \%$ 添加することによ りマクロセル腐食を効果的に抑制することが可能である と考えられる。

\subsection{SGP 鋼管試験片の目視観察及び 重量減少測定結果}

\subsection{1 土壤中の SGP 鋼管試験片}

長期試験終了後（862 日経過後）にお ける土壤中の SGP 鋼管試験片は褐色の 酸化被膜に覆われ，この被膜を除去した 鉄鋼母材表面は全面腐食を呈しており， 孔食はほとんど見られなかった.SGP 鋼 管試験片の重量減少実測結果 $W_{\mathrm{g}}$ （露出 部単位面積あたり；g/ $\mathrm{cm}^{2}$ ) を Table 3 に示す.（A)，(B)などの表記は Fig. 5〜7 の図中の試験体のものと対応している. 式 (1) と同様に重量減少に基づくマクロ セル腐食抑制率 $I_{\mathrm{w}}(\%)$ を式 (2)により定 義する。

$$
I_{\mathrm{w}}=100\left(W_{\mathrm{g}}^{0}-W_{\mathrm{g}}\right) / W_{\mathrm{g}}{ }^{0}
$$

ここに, $W_{\mathrm{g}}^{0}$ 及び $W_{\mathrm{g}}$ は尿酸添加前及び 添加時における露出部単位面積あたりの
重量減少測定值 $\left(\mathrm{g} / \mathrm{cm}^{2}\right)$ である。 $I_{\mathrm{w}}$ の計算にあたり, $W_{0}$ には尿酸を添加しない試験体 $(\mathrm{A}),(\mathrm{B})$ における值の 平均值 $\left(0.075 \mathrm{~g} / \mathrm{cm}^{2}\right)$ を用いた. $I_{\mathrm{w}}$ の尿酸添加濃度依存 性を Fig. 9 に示す． 尿酸添加量が $3.0 \%$ 以下のものについ ては重量減少に抑制効果が見られなかったが，10\%添加 したものについては重量減少が抑制され， $I_{\mathrm{c}}$ と同様の傾 向が見られた。

Fig. 9 で全体的に $I_{\mathrm{w}}$ の絶対值が $I_{\mathrm{c}}$ より小さい傾向を示 すのは，実測された重量減少 $\left(W_{\mathrm{g}}\right)$ にはマクロセル腐食 以外にミクロセル腐食に起因するものも含まれているた めと考えられる。これを考察するため, 各コンクリート 試験体に対する測定全期間（0～862 日）におけるマクロ 七ル腐食電流密度の平均值から式 $(3)$ により腐食減量 $W_{\mathrm{i}}$ $\left(\mathrm{g} / \mathrm{cm}^{2}\right)$ を求めた。この結果を Table 3 に併せて示す.

$$
W_{\mathrm{i}}=i^{\mathrm{av}} M_{\mathrm{Fe}} T /(2 F)
$$

ここに， $i^{\mathrm{av}}$ はマクロセル腐食電流密度の全期間における 平均值 $\left(\mathrm{A} / \mathrm{cm}^{2}\right), F$ はファラデー定数, $M_{\mathrm{Fe}}$ は鉄の原子 量 $(55.85), T$ は反応時間 $(862$ 日; $74476800 \mathrm{~s})$ である. 前節で Fig. 9 の $I_{\mathrm{c}}$ を求めた場合と同様に, 平均電流值を 算出するに当たり, 負方向の電流（コンクリート側がア ノードとなる）は土㙵中の SGP 鋼管試験片の腐食を促進 しないため，これを 0 として求めている. Table 3 には $W_{\mathrm{i}}$ と実測の重量減少 $W_{\mathrm{g}}$ との比 $R_{\mathrm{w}}$ の值 $\left(W_{\mathrm{i}} / W_{\mathrm{g}}\right)$ も併せ て示した. $R_{\mathrm{w}}$ は $0.06 \sim 0.17$ で，これはマクロセル腐食よ りもミクロセル腐食による腐食減量が大きかったことを 示している。また，尿酸無添加の場合について SGP 鋼管 試験片の重量減少から鉄の密度 $7.87 \mathrm{gcm}^{-3}$ 5) を用いて減 肉速度を求めると, 試験体 $(\mathrm{A}),(\mathrm{B})$ とも約 $0.04 \mathrm{~mm} / \mathrm{y}$ で, この值は土㙵中における鋼管の通常の腐食（ミクロセル 腐食）によるもの（最小 $0.0036 \mathrm{~mm} / \mathrm{y}$, 最大 $0.064 \mathrm{~mm} / \mathrm{y}$, 平均で $0.02 \mathrm{~mm} / \mathrm{y}$ 程度) ${ }^{6)}$ と同程度であった。このよう に今回の実験条件では, マクロセル腐食よりもミクロセ ル腐食による腐食減量のほうが支配的であったため, Fig. 9 で， $I_{\mathrm{w}}$ には $I_{\mathrm{c}}$ に比べ，マクロセル腐食抑制に伴う 腐食抑制効果が現れにくかったものと考えられる。

\subsection{2 コンクリート試験体中の SGP 鋼管試験片}

コンクリート試験片内部の SGP 鋼管試験片の目視観察 結果を Table 4 に示す。 $0.3 \%$ を添加した試験片 $(\mathrm{B})$ ，及

Table 3 Averaged macro-cell corrosion currents and weight losses estimated from the currents (0-862 days).

\begin{tabular}{lcccc}
\hline $\begin{array}{l}\text { Uric Acid Dosage } \\
\text { to Concrete } \\
\text { Test Specimen }\end{array}$ & $\begin{array}{l}\text { Weight Loss } \\
(\text { measurement) } \\
\left(W_{g}^{*} ; / \mathrm{cm}^{2}\right)\end{array}$ & $\begin{array}{l}\text { Averaged } \\
\text { Current } \\
(j a r, \\
\left.\mu \mathrm{A} / \mathrm{cm}^{2}\right)^{* 1}\end{array}$ & $\begin{array}{c}\text { Weight Loss } \\
(\text { Estimated } \\
\text { from Current) } \\
\left(W_{i} \mathrm{~g} / \mathrm{cm}^{2}\right)\end{array}$ & $R_{W}\left(W_{i} / \boldsymbol{W}_{g}\right)$ \\
\hline No Dosage (A) & 0.074 & 0.57 & 0.012 & 0.17 \\
\hline No Dosage (B) & 0.076 & 0.43 & 0.009 & 0.12 \\
\hline $0.3 \%$ Uric acid (A) & 0.087 & 0.54 & 0.012 & 0.13 \\
\hline $0.3 \%$ Uric acid (B) & 0.075 & 0.47 & 0.010 & 0.13 \\
\hline $3.0 \%$ Uric acid (A) & 0.083 & 0.63 & 0.014 & 0.16 \\
\hline $3.0 \%$ Uric acid (B) & 0.079 & 0.41 & 0.009 & 0.11 \\
\hline $10 \%$ Uric acid (A) & 0.053 & 0.18 & 0.004 & 0.07 \\
\hline $10 \%$ Uric acid (B) & 0.068 & 0.18 & 0.004 & 0.06 \\
\hline
\end{tabular}

${ }^{*} 1$ : Currents less than zero are converted to 0 for the estimation of weight losses. 
び 10\%を添加した試験片 (A)，(B)でそれぞれ露出面積の 約 $2,6,12 \%$, いずれも試験片端部に褐色の変色が見ら れたが, これ以外のものについては全面腐食, 孔食, 変 色とも認められなかった. 変色の見られた試験片を土袞 中の鋼管試験片と同様に酸洗い処理して変色部を除去し たところ孔食や識別可能な腐食損傷は認められなかっ た。 また, 最も変色面積の大きい $10 \%$ 添加試験片 (B)で も有意差以上 (約 $0.25 \mathrm{~g} ; 8 \mathrm{mg} / \mathrm{cm}^{2}$ ) の重量減少は観測 されず，この変色はコンクリート中の鋼管を使用する上 で特に大きな影響はないと思われる。

この変色の原因について詳細は検討中であるが, 3.1 節 で述べたように，10\%の尿酸を添加した試験体では負方 向の電流が観測され，一時的にコンクリート試験体内部 の鋼管試験片でマクロセル腐食が進行したこととの関連 が考えられる. $W_{\mathrm{i}}$ を求めたものと同じ手法でこの電流に よる腐食減量を求めると，10\%添加時の試験体 $(\mathrm{A})$ で約 $1.6 \mathrm{mg}\left(0.051 \mathrm{mg} / \mathrm{cm}^{2}\right)$, (B) で約 $7.3 \mathrm{mg}\left(0.23 \mathrm{mg} / \mathrm{cm}^{2}\right)$ である。これから求めた露出部の減肉深さは試験体 $(\mathrm{A})$ で約 $6.5 \times 10^{-5} \mathrm{~mm}$ ), (B) で約 $3.0 \times 10^{-4} \mathrm{~mm}$ であり，ま た，この電流が変色部の面積（(A) : 露出面積の $6 \%$, （B）：12\%）に集中して流れた場合でも，減肉深さは $1.1 \times 10^{-3}$ 及び $2.5 \times 10^{-3} \mathrm{~mm}$ である.これらの值は, 前 記の土壤中における鋼管の通常の腐食（ミクロセル腐食） に対する減肉速度より求めた 862 日間の減肉深さ（最小 $1.5 \times 10^{-3} \mathrm{~mm}$, 最大 $2.7 \times 10^{-2} \mathrm{~mm}$, 平均 $8.5 \times 10^{-3} \mathrm{~mm}$ 程度）と比較しても小さく, また前記の通りこの電流は 減少する傾向を見せていることを考慮すると，この電流 が SGP 試験片の腐食の原因であった場合でも，実用上特 に問題はないと思われる。コンクリート模擬水溶液（飽 和 $\mathrm{Ca}(\mathrm{OH})_{2}$ 水溶液）を用いた検討で 7$)$ ，水溶液中の尿酸 濃度が極めて高濃度の場合は，この中に浸漬した鉄鋼表

Table 4 Visual observation and weight losses of SGP steel pipe test specimens embedded in concrete after electrical connection with those in soil for 862 days.

\begin{tabular}{|c|c|c|}
\hline $\begin{array}{l}\text { Uric Acid Dosage } \\
\text { to Concrete } \\
\text { Test Specimen }\end{array}$ & $\begin{array}{l}\text { Visual } \\
\text { Observation }\end{array}$ & $\begin{array}{l}\text { Weight } \\
\text { Loss }^{* 1} \\
\left(\mathrm{~g} / \mathrm{cm}^{2}\right) \\
\end{array}$ \\
\hline No Dosage (A) & No Corrosion & - \\
\hline No Dosage (B) & No Corrosion & - \\
\hline $0.3 \%$ Uric acid (A) & No Corrosion & - \\
\hline $0.3 \%$ Uric acid (B) & $\begin{array}{l}\text { Brown Rust } \\
\text { ( } 2 \% \text { of the } \\
\text { surface area) } \\
\text { No Pitting }\end{array}$ & - \\
\hline $3.0 \%$ Uric acid (A) & No Corrosion & - \\
\hline $3.0 \%$ Uric acid (B) & No Corrosion & - \\
\hline $10 \%$ Uric acid (A) & $\begin{array}{l}\text { Brown Rust } \\
\text { ( } 6 \% \text { of the } \\
\text { surface area) } \\
\text { No Pitting }\end{array}$ & - \\
\hline $10 \%$ Uric acid (B) & $\begin{array}{l}\text { Brown Rust } \\
\text { ( } 12 \% \text { of the } \\
\text { surface area) } \\
\text { No Pitting }\end{array}$ & $\begin{array}{l}\text { Less than } \\
\text { Detection } \\
\text { Limit } \\
(<0.008)\end{array}$ \\
\hline
\end{tabular}

面のカソード反応が抑制される反面, アノード反応が加 速される現象が見られており7), 負方向の電流の発生は これと関連があることも考えられる。今回の測定では, 10\%添加の場合には負方向の電流が見られたが，3\%以 下の添加の場合にはこの電流は見られなかった。このた め，3〜10\%の間に負方向の電流を生ずることなく， か つ効果的にマクロセル腐食を抑制することのできる，さ らに最適な尿酸添加量が存在する可能性もあると考えら れる。

また，このほかの原因として, SGP 鋼管試験片の変色 は $0.3 \%$ 試験体 $(\mathrm{B})$ のように負方向の電流が観測されな いものにも見られ，また，変色は試験片両端に集中する 傾向を見せていることから, かぶり厚の小さい雨端部で は水の浸透により試験片周囲の間隙水の $\mathrm{pH}$ 值が低下し たために，腐食が進行した可能性も考えられる。

以上のように，今回の検討により尿酸をセメント重量 比で $10 \%$ 添加することにより効果的に土壌中の SGP 鋼 管試験片のマクロセル腐食を抑制できることを確認する ことができ，また，尿酸添加がコンクリート内部の SGP 鋼管試験片に実用上問題となるような支障を引き起こさ ないことが分った. 本手法は, 埋設配管がコンクリート 建築物の床，土間などを鉄筋と接触することなく貫通す る場合や, 犬走り（建築物屋外の回廊）の下部などで配 管の上部がコンクリート内に埋め込まれた状態で土壤中 に埋設されている場合など，比較的小規模の設備で，従 来の絶縁継ぎ手などが使用できない事例には特に好適に 適用できるものと考えられる。

\section{4. 今後の予定}

今回の実験条件では，マクロセル腐食よりもミクロセ ル腐食による腐食減量のほうが支配的であり, SGP 鋼管 試験片の重量減少測定結果には顕著なマクロセル腐食抑 制効果が現れなかった。 これについては, 土潩の体積含 水率を上昇させたり土潩中の SGP 鋼管試験片をコンクリ ート試験体により近接させて埋設することなどにより， 土袞中とコンクリート中の SGP 鋼管試験片間の電気抵抗 を減少させ，マクロセル腐食電流を増大させた条件で実 験を行うことよって, 明瞭な抑制効果が得られるよう改 善できるものと考えられるので, 今後実施する予定であ る.また，前章で述べたような，負方向の電流を生じず， 効果的にマクロセル腐食を抑制することのできる最適な 尿酸添加量の探索実験や，コンクリート中の SGP 鋼管試 験片の変色の原因が鋼管試験片両端部からの水の浸透に よるものか否かを明らかにすることを目的とした，両端 部のかぶり厚を大きくしたコンクリート試験体を用いた 実験も行う予定である。ささらに，実用化に向けた，実規 模に近い条件での性能実証試験も実施していく予定であ る.

\section{5. 結言}

尿酸をセメントに添加することにより，コンクリート 内部の鉄鋼表面のカソード反応を抑制し，これと導通す る埋設鋼管材料のコンクリート/土懔系マクロセル腐食 を抑制する手法について，コンクリート試験体と土袞を 
用いた検討を行った。尿酸を添加したコンクリート試験 体（水/セメント比：61\%）内部の SGP 鋼管試験片と, 土壤に埋設した SGP 鋼管試験片との間に流れるマクロセ ル腐食電流変化を 862 日間実測することにより，尿酸を セメント重量比で 10\%添加することによりマクロセル腐 食電流が抑制されること（0～862 日間の電流抑制率：約 64\%）を確認した。この抑制効果は時間と共に増大する 傾向が見られた（297〜862 日間の電流抑制率：78〜 91\%). 0.3\%及び 3.0\%の添加では安定した抑制効果が見 られなかった。電流測定終了後に土壤中の鋼管試験片を 回収して腐食減量を実測した結果でも同様の傾向が見ら れた. $10 \%$ 尿酸を混合したコンクリート試験体では一部 の期間に逆方向の電流（土袞側からコンクリート側 ; コ ンクリート内部の鋼管試験片でマクロセル腐食が進行す ることに対応）が観測されたが，この電流に相当する腐 食減量は軽微（約 $0.051 \sim 0.23 \mathrm{mg} / \mathrm{cm}^{2}$ ) と考えられ, 目 視観察上も孔食などの腐食損傷は観測されず, また, 電 流も時間とともに減少する傾向を示しているため, 特に
実用上問題はないと予想される。これらから尿酸を $10 \%$ 添加することにより，土壌中埋設鋼管のマクロセル腐食 を効果的に抑制することが可能と考えられる.

\section{参考 文 献}

1) M. Yamakawa, Kukichowa $\cdot$ Eiseikougaku, 59 [1] 63 (1985).

2) B. Husock, Corrosion, 17, 391t (1961).

3) N. Nakayama, S. Asakura, Zairyo-to-Kankyo, 57, 449 (2008).

4) K. Mabuchi, T. Kikuchi, H. Midorikawa and M. Aizawa, Zairyo-to-Kankyo, 45, 526 (1996).

5) G. Okamoto, S. Matsuda and I. Matsushima, "Fushokuhannou to sono seigyo,” (腐食反応とその制御), Sangyo Tosho, p.430 (2002).

6) I. Matsushima, Boshoku-Gijutsu (presently Zairyo-toKankyo), 25, 563 (1976).

7) N. Nakayama and A. Obuchi, Electrochemistry, 73 [5] 339 (2005).

(Manuscript received May 27, 2009; in final form July 29, 2009)

\section{要旨}

コンクリート内部の鋼管との導通により生ずる土壌埋設管のマクロセル腐食 (C/S マクロセル腐食) を, 尿酸をセメント添加剤として混合することにより抑制する手法を検討した．尿酸を添加したコンクリート 試験体内部の鉄鋼試験片と，土壤中の鉄鋼試験片の間を流れる電流の実測（862 日間）及び土壌埋設鋼管 の重量減少測定実験により，効果的に上記腐食が抑制されることを確認した。

キーワード コンクリート, マクロセル腐食, 土畩, 鋼管, 腐食抑制剤, 尿酸 